\section{Studi Morfologi Tanaman Sansevieria di Kota Makassar}

\author{
Istiqamah \\ St. Fatmah Hiola \\ Hilda Karim
}

\begin{abstract}
Abstrak. Penelitian ini merupakan penelitian deskriptif yang bertujuan untuk mempelajari karakteristik morfologi dari tumbuhan sansevieria di Kota Makassar. Penelitian ini dilakukan pada bulan Februari sampai Maret 2018. Sampel penelitian diperoleh dari beberapa lokasi, antara lain depot tanaman hias, koleksi pribadi dari St. Fatmah Hiola, dan koleksi pribadi penulis. Pengambilan data dilakukan dengan cara mengamati karakteristik morfologi dari tanaman sansevieria. Dari hasil penelitian diperoleh tanaman sansevieria sebanyak 25 spesies. Tanaman sansevieria di Kota Makassar didominasi oleh spesies dengan warna hijau gelap hingga hijau kelabu, hanya sedikit yang berwarna hijau pucat atau memiliki kombinasi warna kuning, Memiliki bentuk atau bangun daun yang beragam diantaranya adalah bangun jorong (ovalis), memanjang (oblongus), lanset (lanceolatus), hingga bangun paku/dabus atau silinder (subulatus).

Kata Kunci: sansevieria, karakteristik, morfologi, kota makassar.
\end{abstract}

\section{Pendahuluan}

Sansevieria merupakan tanaman yang memiliki keragaman warna dan bentuk daun, serta sering digunakan sebagai tanaman hias baik di dalam maupun di luar rumah sebab tanaman ini dapat tumbuh dalam kondisi sedikit air dan cahaya matahari, serta tidak memerlukan banyak perawatan. Sansevieria memiliki peminat di berbagai belahan dunia baik karena manfaat, keindahan, maupun nilai kepercayaan yang dimilikinya (Imani, 2015).

Tanaman sansevieria memiliki banyak ragam sebab perbanyakan yang dilakukan pada tanaman ini tidak selalu menghasilkan jenis yang sama dengan induknya. Keindahan tanaman sansevieria ditunjukkan dari ragam jenis, bentuk, ukuran, serta warna daun. Keragaman jenis yang ada di alam tak hanya diperoleh dari persilangan tanaman, tetapi juga dari mutasi. Pada tanaman ini sering terjadi mutasi sehingga seringkali anakan yang dihasilkan berbeda dari induknya (Batubara, 2010).

Karakterisasi merupakan suatu kegiatan dalam konservasi plasma nutfah untuk mengetahui sifat morfologi yang dapat dimanfaatkan dalam membedakan antaraksesi, menilai besarnya keragaman genetik, mengidentifikasi varietas, menilai jumlah aksesi dan sebagainya (Hartati dan Darsana, 2014).

Khusus pada tanaman Sansevieria, diketahui memiliki kultivar-kultivar yang mempunyai daun bervariasi dalam bentuk, ukuran, warna, dan teksturnya. Selain bentuknya unik, tanaman Sansevieria mampu memberikan udara bersih bagi ruangan yang ditempatinya, karena tanaman ini dapat menyerap zat berbahaya di udara. Kemampuan tanaman

\section{BIONATURE}

p-ISSN 1411 - 4720

e-ISSN 2654 - 5160

Abstract. This research is a descriptive study which aims to study the morphological characteristics of Sansevieria plants in Makassar City. This research was conducted from February to March 2018. The location of the study was conducted in several areas in

Makassar city which Sansevieria met.

Data collection was done by observing

the morphological characteristics of

Sansevieria plants. The results of the study obtained as many as 25 species of Sansevieria. Sansevieria plants in the city of Makassar are dominated by species with dark green to gray green, only a few are pale green or have a combination of yellow, have a shape or build a variety of leaves such as wake oval (ovalis), elongated (oblongus), lancet (lanceolatus), to subulate or terete (subulatus).

Keywords: sansevieria, characteristics, morphology, makassar city.

Istiqamah

Universitas Negeri Makassar Indonesia

St. Fatmah Hiola

Universitas Negeri Makassar Indonesia

Hilda Karim

Universitas Negeri Makassar Indonesia 
dalam menyerap dan mengakumulasi polutan ternyata dipengaruhi oleh karakteristik morfologi daun, seperti: ukuran, bentuk, dan teksturnya.

\section{Rumusan Masalah}

Berdasarkan uraian diatas permasalahan dalam penelitian ini adalah bagaimanakah karakteristik morfologi tanaman Sansevieria di Kota Makassar?

\section{Fokus Penelitian}

Adapun tujuan dari penelitian adalah untuk mempelajari karakteristik morfologi dari tumbuhan sansevieria di Kota Makassar.

\section{Metode Penelitian}

\section{Jenis Penelitian}

Jenis penelitian ini merupakan penelitian deskriptif untuk mempelajari karakteristik morfologi tanaman Sansevieria yang ada di kota Makassar.

\section{Analisis Data}

Data yang diperoleh dari hasil pengamatan dianalisis dengan data deskriptif, yaitu menyederhanakan data dan menata data secara keseluruhan dari objek yang diamati. Data yang diperoleh disajikan dalam bentuk tabel.

\section{Hasil Penelitian}

Data kualitatif berupa deskripsi tanaman sansevieria dapat dilihat pada tabel 1, data kuantitatif berupa pengukuran panjang, lebar, dan tebal daun tanaman sansevieria di kota Makassar dapat dilihat pada tabel 1.

Tabel 1. Data Kualitatif Sansevieria

\begin{tabular}{|c|c|c|}
\hline No & Spesies & Morfologi \\
\hline 1 & Sansevieria trifasciata 'pagoda'. & $\begin{array}{l}\text { - Habitus: terna (herba), tanaman menahun, terdapat } \\
\text { rimpang (rhizoma). } \\
\text { - Akar: akar serabut, kecil, bulat, warna putih. } \\
\text { - Rimpang: tumbuh mendatar atau menjalar, bulat, beruas, } \\
\text { berserat, warna kecoklatan. } \\
\text { - Daun: daun tunggal, tersebar, daun duduk (sessilis), roset } \\
\text { akar, tidak berupih, tidak bertangkai, bangun jorong } \\
\text { (ovalis/ellipticus), pangkal membulat (rotundatus), ujung } \\
\text { meruncing (acuminatus), tepi rata (integer) warna kuning } \\
\text { kehijauan; permukaan atas dan bawah licin (laevis), } \\
\text { warna hijau tua. } \\
\text { - Corak/motif: cross banding (garis warna) kuning } \\
\text { kehijauan dengan warna putih kekuningan di bagian tepi. } \\
\text { - Bunga: tidak ditemukan. }\end{array}$ \\
\hline 2 & Sansevieria trifasciata 'Gold flame' & $\begin{array}{l}\text { - Habitus: terna (herba), tanaman menahun, terdapat } \\
\text { rimpang (rhizoma). } \\
\text { - Akar: akar serabut, kecil, bulat, warna putih-kecoklatan. } \\
\text { - Rimpang: tumbuh mendatar, bulat, beruas, berserat, } \\
\text { oranye-kecoklatan. } \\
\text { - Daun: daun tunggal, daun duduk (sessilis), roset akar, } \\
\text { tidak berupih, tidak bertangkai, bangun memanjang }\end{array}$ \\
\hline
\end{tabular}




\begin{tabular}{|c|c|c|}
\hline & & $\begin{array}{l}\text { (oblongus) hingga lanset (lanceolatus), pangkal membulat } \\
\text { (rotundatus) warna putih, ujung meruncing (acuminatus), } \\
\text { tepi rata (integer) warna kuning cerah, permukaan atas } \\
\text { licin mengkilat (laevis-nitidus) didominasi warna kuning } \\
\text { cerah dengan warna hijau tua di bagian tengah, } \\
\text { permukaan bawah licin mengkilat (laevis-nitidus) warna } \\
\text { hijau tua. } \\
\text { - Corak/motif: cross banding (garis warna) hijau muda, } \\
\text { samar-samar di permukaan atas, terlihat jelas di } \\
\text { permukaan bawah. } \\
\text { - Bunga: tidak ditemukan. }\end{array}$ \\
\hline 3 & Sansevieria trifasciata 'metalica' & $\begin{array}{l}\text { - Habitus: terna (herba), tanaman menahun, terdapat } \\
\text { rimpang (rhizoma). } \\
\text { - Akar: serabut, kecil, bulat, warna oranye. } \\
\text { - Rimpang: tumbuh mendatar/berbaring, bulat, beruas, } \\
\text { berserat, warna putih kecoklatan. } \\
\text { - Daun: daun tunggal, daun duduk (sessilis), roset akar, } \\
\text { tidak berupih, tidak bertangkai, bangun memanjang } \\
\text { (oblongus), pangkal membulat (rotundatus) warna putih, } \\
\text { ujung meruncing (acuminatus), tepi rata (integer), } \\
\text { permukaan atas dan bawah licin mengkilat (laevis-nitidus) } \\
\text { warna hijau keabuan. } \\
\text { - Corak/motif: strip/garis vertikal hijau muda. } \\
\text { - Bunga: tidak ditemukan. }\end{array}$ \\
\hline 4 & $\begin{array}{l}\text { Sansevieria trifasciata 'golden hahnii } \\
\text { philippines' }\end{array}$ & $\begin{array}{l}\text { - Habitus: terna (herba), tanaman menahun, terdapat } \\
\text { rimpang (rhizoma). } \\
\text { - Akar: serabut, kecil, bulat, warna putih hingga coklat. } \\
\text { - Rimpang: tumbuh menjalar/mendatar, bulat, beruas, } \\
\text { berserat, berwarna hijau hingga coklat tua. } \\
\text { - Daun: daun tunggal, daun duduk (sessilis), roset akar, } \\
\text { tidak berupih, tidak bertangkai, bangun jorong (ovalis) } \\
\text { hingga memanjang (oblongus), pangkal membulat } \\
\text { (rotundatus), ujung meruncing (acuminatus), tepi rata } \\
\text { (integer) berwarna hijau, permukaan atas dan bawah licin } \\
\text { mengkilat (laevis-nitidus), warna kuning diikuti warna } \\
\text { hijau dari pangkal hingga ujung daun pada pertengahan } \\
\text { daun. } \\
\text { - Corak/motif: cross banding (garis warna) putih } \\
\text { kekuningan di permukaan bawah daun. } \\
\text { - Bunga: tidak ditemukan. }\end{array}$ \\
\hline 5 & $\begin{array}{l}\text { Sansevieria trifasciata 'golden hahnii } \\
\text { philippines mutation' }\end{array}$ & $\begin{array}{l}\text { - Habitus: terna (herba), tanaman menahun, terdapat } \\
\text { rimpang (rhizoma). } \\
\text { - Akar: serabut, kecil, bulat, warna putih hingga coklat. } \\
\text { - Rimpang: tumbuh menjalar/mendatar, bulat, beruas, } \\
\text { berserat, berwarna hijau hingga coklat tua. } \\
\text { - Daun: daun tunggal, daun duduk (sessilis), roset akar, } \\
\text { tidak berupih, tidak bertangkai, bangun jorong (ovalis) } \\
\text { hingga memanjang (oblongus), pangkal membulat } \\
\text { (rotundatus), ujung meruncing (acuminatus), tepi rata } \\
\text { (integer) berwarna hijau, permukaan atas dan bawah licin } \\
\text { mengkilat (laevis-nitidus), warna kuning. } \\
\text { - Corak/motif: cross banding (garis warna) putih } \\
\text { kekuningan. } \\
\text { - Bunga: tidak ditemukan. }\end{array}$ \\
\hline 6 & Sansevieria nelsonii & $\begin{array}{l}\text { - Habitus: terna (herba), tanaman menahun, terdapat } \\
\text { rimpang (rhizoma). } \\
\text { - Akar: serabut, kecil, bulat, warna putih hingga coklat. }\end{array}$ \\
\hline
\end{tabular}




\begin{tabular}{|c|c|c|}
\hline & & $\begin{array}{l}\text { - Rimpang: tumbuh menjalar/mendatar, bulat, beruas, } \\
\text { berserat, berwarna merah kecoklatan. } \\
\text { - Daun: daun tunggal, daun duduk (sessilis), roset akar, } \\
\text { tidak berupih, tidak bertangkai, bangun lanset } \\
\text { (lanceolatus), pangkal membulat (rotundatus), ujung } \\
\text { meruncing (acuminatus), tepi rata (integer) berwarna } \\
\text { hijau muda, permukaan atas dan bawah licin mengkilat } \\
\text { (laevis-nitidus), warna hijau tua. } \\
\text { - Corak/motif: cross banding (garis warna) hijau muda, } \\
\text { terlihat jelas pada permukaan bawah daun. } \\
\text { - Bunga: tidak ditemukan. }\end{array}$ \\
\hline 7 & Sansevieria javanica. & $\begin{array}{l}\text { - Habitus: terna (herba), tanaman menahun, terdapat } \\
\text { rimpang (rhizoma). } \\
\text { - Akar: serabut, kecil, bulat, warna putih hingga kecoklatan. } \\
\text { - Rimpang: tumbuh menjalar (mendatar), bulat, beruas, } \\
\text { berserat, berwarna coklat. } \\
\text { - Daun: daun tunggal, daun duduk (sessilis), roset akar, } \\
\text { tidak berupih, tidak bertangkai, bangun lanset } \\
\text { (lanceolatus), pangkal membulat (rotundatus), ujung } \\
\text { meruncing (acuminatus), tepi rata (integer), permukaan } \\
\text { atas licin mengkilat (laevis-nitidus) dengan satu alur dan } \\
\text { permukaan bawah kasap (scaber) dengan beberapa } \\
\text { garis/alur dari pangkal hingga ujung daun, warna hijau } \\
\text { tua. } \\
\text { - Corak/motif: cross banding (garis warna) hijau muda. } \\
\text { - Bunga: tidak ditemukan. }\end{array}$ \\
\hline 8 & Sansevieria trifasciata 'green' & $\begin{array}{l}\text { - Habitus: terna (herba), tanaman menahun, terdapat } \\
\text { rimpang (rhizoma). } \\
\text { - Akar: serabut, kecil, bulat, warna putih hingga kecoklatan } \\
\text { - Rimpang: tumbuh menjalar/mendatar, bulat, beruas, } \\
\text { berserat, berwarna hijau hingga merah kecoklatan. } \\
\text { - Daun: daun tunggal, daun duduk (sessilis), roset akar, } \\
\text { tidak berupih, tidak bertangkai, bangun memanjang } \\
\text { (oblongus), pangkal membulat (rotundatus), ujung } \\
\text { meruncing (acuminatus), tepi rata (integer), permukaan } \\
\text { atas dan bawah licin mengkilat (laevis-nitidus), warna } \\
\text { hijau tua. } \\
\text { - Corak/motif: cross banding (garis warna) hijau muda di } \\
\text { permukaan atas dan warna hijau keabuan (hijau silver) di } \\
\text { permukaan bawah daun. } \\
\text { - Bunga: tidak ditemukan. }\end{array}$ \\
\hline 9 & Sansevieria malawi 'midnight' & $\begin{array}{l}\text { - Habitus: terna (herba), tanaman menahun, terdapat } \\
\text { rimpang (rhizoma). } \\
\text { - Akar: serabut, kecil, bulat, warna putih hingga kecoklatan } \\
\text { - Rimpang: tumbuh menjalar/mendatar, bulat, beruas, } \\
\text { berserat, berwarna merah kecoklatan. } \\
\text { - Daun: daun tunggal, daun duduk (sessilis), roset akar, } \\
\text { tidak berupih, tidak bertangkai, bangun lanset } \\
\text { (lanceolatus), pangkal membulat (rotundatus), ujung } \\
\text { meruncing (acuminatus), tepi rata (integer) hingga } \\
\text { berombak (repandus) kecoklatan, permukaan atas dan } \\
\text { bawah licin mengkilat (laevis-nitidus), warna hijau tua. } \\
\text { - Corak/motif: cross banding (garis warna) hijau muda, } \\
\text { strip/garis vertikal hijau tua. } \\
\text { - Bunga: tidak ditemukan. }\end{array}$ \\
\hline 10 & $\begin{array}{l}\text { Sansevieria trifasciata 'gold banner } \\
\text { twister' }\end{array}$ & $\begin{array}{l}\text { - Habitus: terna (herba), tanaman menahun, terdapat } \\
\text { rimpang (rhizoma). }\end{array}$ \\
\hline
\end{tabular}




\begin{tabular}{|c|c|c|}
\hline & & $\begin{array}{l}\text { - Akar: serabut, kecil, bulat, warna putih hingga coklat. } \\
\text { - Rimpang: tumbuh menjalar/mendatar, bulat, beruas, } \\
\text { berserat, berwarna coklat. } \\
\text { - Daun: daun tunggal, daun duduk (sessilis), roset akar, } \\
\text { tidak berupih, tidak bertangkai, bangun jorong- } \\
\text { memanjang (elliptico-oblongus), pangkal membulat } \\
\text { (rotundatus), ujung meruncing (acuminatus), tepi rata } \\
\text { (integer) warna hijau, permukaan atas licin mengkilat } \\
\text { (laevis-nitidus) dan bawah licin (laevis), warna kuning } \\
\text { bercampur hijau. } \\
\text { - Corak/motif: cross banding (garis warna) putih-hijau. } \\
\text { - Bunga: tidak ditemukan }\end{array}$ \\
\hline 11 & Sansevieria trifasciata 'aurentii' & $\begin{array}{l}\text { - Habitus: terna (herba), tanaman menahun, terdapat } \\
\text { rimpang (rhizoma). } \\
\text { - Akar: serabut, kecil, bulat, warna putih hingga coklat } \\
\text { - Rimpang: tumbuh menjalar/mendatar, bulat, beruas, } \\
\text { berserat, berwarna kecoklatan. } \\
\text { - Daun: daun tunggal, daun duduk (sessilis), roset akar, } \\
\text { tidak berupih, tidak bertangkai, bangun memanjang } \\
\text { (oblongus), pangkal membulat (rotundatus), ujung } \\
\text { meruncing (acuminatus), tepi rata (integer) warna kuning, } \\
\text { permukaan atas dan bawah licin mengkilat (laevis- } \\
\text { nitidus), warna hijau gelap. } \\
\text { - Corak/motif: cross banding (garis warna) hijau muda di } \\
\text { bagian tengah dan kuning di tepi daun. } \\
\text { - Bunga: tidak ditemukan. }\end{array}$ \\
\hline 12 & Sansevieria masoniana & $\begin{array}{l}\text { - Habitus: terna (herba), tanaman menahun, terdapat } \\
\text { rimpang (rhizoma). } \\
\text { - Akar: serabut, sedang, bulat, warna putih hingga coklat. } \\
\text { - Rimpang: tumbuh menjalar/mendatar, bulat, berukuran } \\
\text { besar, beruas, berserat, berwarna coklat muda. } \\
\text { - Daun: daun tunggal, daun duduk (sessilis), roset akar, } \\
\text { tidak berupih, tidak bertangkai, bangun jorong } \\
\text { (ovalis/ellipticus), pangkal membulat (rotundatus), ujung } \\
\text { runcing (acutus), tepi rata (integer) merah keunguan, } \\
\text { permukaan atas dan bawah kasap (scaber), warna hijau } \\
\text { tua. } \\
\text { - Corak/motif: spot (totol) hijau muda. } \\
\text { - Bunga: tidak ditemukan. }\end{array}$ \\
\hline 13 & Sansevieria patens & $\begin{array}{l}\text { - Habitus: terna (herba), tanaman menahun, terdapat } \\
\text { rimpang (rhizoma). } \\
\text { - Akar: serabut, sedang, bulat, warna putih hingga coklat } \\
\text { - Rimpang: tumbuh menjalar/mendatar, bulat, besar, } \\
\text { beruas, berserat, berwarna oranye kecoklatan. } \\
\text { - Daun: daun tunggal, daun duduk (sessilis), roset akar, } \\
\text { tidak berupih, tidak bertangkai, bangun paku/dabus } \\
\text { (subulatus), pangkal rata (rotundatus), ujung runcing } \\
\text { (acutus), permukaan kasap (scaber), tebal dan kaku, } \\
\text { terdapat saluran (channel) di pangkal dan beberapa } \\
\text { alur/garis memanjang dari pangkal hingga ujung daun, } \\
\text { warna hijau tua. } \\
\text { - Corak/motif: cross banding (garis warna) hijau keabuan, } \\
\text { tidak terlihat jelas. } \\
\text { - Bunga: tidak ditemukan. }\end{array}$ \\
\hline 14 & Sansevieria trifasciata 'moonshine I' & $\begin{array}{l}\text { - Habitus: terna (herba), tanaman menahun, terdapat } \\
\text { rimpang (rhizoma). } \\
\text { - Akar: serabut, kecil, bulat, warna putih hingga coklat }\end{array}$ \\
\hline
\end{tabular}




\begin{tabular}{|c|c|c|}
\hline & & $\begin{array}{l}\text { - Rimpang: tumbuh menjalar/mendatar, bulat, beruas, } \\
\text { berserat, berwarna coklat muda. } \\
\text { - Daun: daun tunggal, daun duduk (sessilis), roset akar, } \\
\text { tidak berupih, tidak bertangkai, bangun sudip } \\
\text { (spathulatus), pangkal membulat (rotundatus), ujung } \\
\text { meruncing (acuminatus), tepi rata (integer) berwarna } \\
\text { hijau gelap, permukaan atas dan bawah licin-mengkilat } \\
\text { (laevis-nitidus), warna putih kehijauan hingga hijau tua. } \\
\text { - Corak/motif: cross banding (garis warna) hijau tua, } \\
\text { kadang terlihat samar. } \\
\text { - Bunga: tidak ditemukan }\end{array}$ \\
\hline 15 & Sansevieria trifasciata 'moonshine II' & $\begin{array}{l}\text { - Habitus: terna (herba), tanaman menahun, terdapat } \\
\text { rimpang (rhizoma). } \\
\text { - Akar: serabut, kecil, bulat, warna putih hingga coklat } \\
\text { - Rimpang: tumbuh menjalar/mendatar, bulat, beruas, } \\
\text { berserat, berwarna coklat muda. } \\
\text { - Daun: daun tunggal, daun duduk (sessilis), roset akar, } \\
\text { tidak berupih, tidak bertangkai, bangun jorong } \\
\text { (ovalis/ellipticus) hingga memanjang (oblongus), pangkal } \\
\text { membulat (rotundatus), ujung meruncing (acuminatus), } \\
\text { tepi rata (integer) berwarna hijau tua, permukaan atas } \\
\text { dan licin-mengkilat (laevis-nitidus), warna abu-abu } \\
\text { dengan semburat hijau. } \\
\text { - Corak/motif: cross banding (garis warna) hijau tua, } \\
\text { kadang terlihat samar. } \\
\text { - Bunga: tidak ditemukan. }\end{array}$ \\
\hline 16 & Sansevieria cylindrica & $\begin{array}{l}\text { - Habitus: terna (herba), tanaman menahun, terdapat } \\
\text { rimpang (rhizoma). } \\
\text { - Akar: serabut, sedang, bulat, warna putih hingga coklat } \\
\text { - Rimpang: tumbuh menjalar/mendatar, bulat, beruas, } \\
\text { berserat, berwarna coklat muda. } \\
\text { - Daun: daun tunggal, daun duduk (sessilis), roset akar, } \\
\text { tidak berupih, tidak bertangkai, bangun paku (subulatus), } \\
\text { pangkal membulat (rotundatus), ujung runcing (acutus), } \\
\text { seluruh daun kaku, permukaan kasap (scaber), warna } \\
\text { hijau, terdapat alur halus sepanjang daun. } \\
\text { - Corak/motif: cross banding (garis warna) hijau muda } \\
\text { namun tidak terlihat jelas, dan strip/garis vertikal warna } \\
\text { hijau tua. } \\
\text { - Bunga: tidak ditemukan. }\end{array}$ \\
\hline 17 & Sansevieria trifasciata 'parva stick' & $\begin{array}{l}\text { - Habitus: terna (herba), tanaman menahun, terdapat } \\
\text { rimpang (rhizoma). } \\
\text { - Akar: serabut, kecil, bulat, warna putih } \\
\text { - Rimpang: tumbuh menjalar/mendatar, bulat, beruas, } \\
\text { berserat, berwarna coklat muda. } \\
\text { - Daun: daun tunggal, daun duduk (sessilis), tumbuh tegak, } \\
\text { tidak berupih, tidak bertangkai, bangun pedang } \\
\text { (ensiformis), pangkal membulat (rotundatus), ujung } \\
\text { meruncing (acuminatus), tepi rata (integer), permukaan } \\
\text { atas dan bawah licin-mengkilat (laevis-nitidus), warna } \\
\text { hijau gelap. } \\
\text { - Corak/motif: cross banding (garis warna) hijau muda. } \\
\text { - Bunga: tidak ditemukan. }\end{array}$ \\
\hline 18 & Sansevieria aethiopica 'mutasi'. & $\begin{array}{l}\text { - Habitus: terna (herba), tanaman menahun, terdapat } \\
\text { rimpang (rhizoma). } \\
\text { - Akar: serabut, kecil, bulat, warna putih. } \\
\text { - Rimpang: bulat, ukuran sedang, beruas, berserat, }\end{array}$ \\
\hline
\end{tabular}




\begin{tabular}{|c|c|c|}
\hline & & $\begin{array}{l}\text { berwarna putih. } \\
\text { - Daun: daun tunggal, daun duduk (sessilis), roset akar, } \\
\text { tidak berupih, tidak bertangkai, dabus atau paku } \\
\text { (subulatus) dengan saluran (channel) dari pangkal hingga } \\
\text { ujung daun, pangkal rata (truncatus), ujung meruncing } \\
\text { (acuminatus), tepi rata (integer) berwarna kemerahan, } \\
\text { permukaan atas dan bawah licin (laevis), warna hijau tua. } \\
\text { - Corak/motif: cross banding (garis warna) hijau muda. } \\
\text { - Bunga: tidak ditemukan. }\end{array}$ \\
\hline 19 & Sansevieria grandis & $\begin{array}{l}\text { - Habitus: terna (herba), tanaman menahun, terdapat } \\
\text { rimpang (rhizoma). } \\
\text { - Akar: serabut, kecil, bulat, warna putih. } \\
\text { - Rimpang: tumbuh menjalar/mendatar, bulat, beruas, } \\
\text { berserat, berwarna coklat muda. } \\
\text { - Daun: daun tunggal, daun duduk (sessilis), roset akar, } \\
\text { tidak berupih, bertangkai, bangun jorong (ellipticus), } \\
\text { pangkal membulat (rotundatus), ujung runcing (acutus), } \\
\text { tepi rata (integer) berwarna coklat muda, permukaan atas } \\
\text { dan bawah licin (laevis), warna hijau kelabu. } \\
\text { - Corak/motif: cross banding (garis warna) hijau tua. } \\
\text { - Bunga: tidak ditemukan. }\end{array}$ \\
\hline 20 & Sansevieria trifasciata 'tiger stripe' & $\begin{array}{l}\text { - Habitus: terna (herba), tanaman menahun, terdapat } \\
\text { rimpang (rhizoma). } \\
\text { - Akar: serabut, kecil, bulat, warna putih. } \\
\text { - Rimpang: tumbuh menjalar/mendatar, bulat, beruas, } \\
\text { berserat, berwarna coklat muda. } \\
\text { - Daun: daun tunggal, daun duduk (sessilis), roset akar, } \\
\text { tidak berupih, tidak bertangkai, bangun jorong } \\
\text { (ovalis/ellipticus) hingga memanjang (oblongus), pangkal } \\
\text { membulat (rotundatus), ujung runcing (acutus), tepi rata } \\
\text { (integer) berwarna kecoklatan, permukaan atas dan } \\
\text { bawah licin (laevis), warna hijau muda. } \\
\text { - Corak/motif: cross banding (garis warna) hijau silver } \\
\text { (hijau perak). } \\
\text { - Bunga: tidak ditemukan. }\end{array}$ \\
\hline 21 & Sansevieria canaliculata & $\begin{array}{l}\text { - Habitus: terna (herba), tanaman menahun, terdapat } \\
\text { rimpang (rhizoma). } \\
\text { - Akar: serabut, kecil, bulat, warna putih } \\
\text { - Rimpang: tumbuh menjalar/mendatar, bulat, beruas, } \\
\text { berserat, berwarna coklat muda. } \\
\text { - Daun: daun tunggal, daun duduk (sessilis), tidak berupih, } \\
\text { tidak bertangkai, bangun dabus atau paku (subulatus), } \\
\text { pangkal membulat (rotundatus), ujung meruncing } \\
\text { (acuminatus), permukaan licin (laevis), warna hijau muda, } \\
\text { terdapat beberapa alur vertikal sepanjang daun. } \\
\text { - Corak/motif: tidak ada. } \\
\text { - Bunga: tidak ditemukan. }\end{array}$ \\
\hline 22 & Sansevieria concinna & $\begin{array}{l}\text { - Habitus: terna (herba), tanaman menahun, terdapat } \\
\text { rimpang (rhizoma). } \\
\text { - Akar: serabut, kecil, bulat, warna putih. } \\
\text { - Rimpang: tumbuh mndatar, membentuk spiral, bulat, } \\
\text { beruas, berserat, berwarna coklat muda. } \\
\text { - Daun: daun tunggal, tidak berupih, bertangkai, bangun } \\
\text { jorong-memanjang (elliptico-oblongus), pangkal membulat } \\
\text { (rotundatus), ujung runcing (acutus), tepi rata (integer), } \\
\text { permukaan atas dan bawah licin (laevis), warna hijau. } \\
\text { - Corak/motif: cross banding (garis warna) hijau tua. }\end{array}$ \\
\hline
\end{tabular}




\begin{tabular}{|c|c|c|}
\hline & & - Bunga: tidak ditemukan. \\
\hline 23 & Sansevieria francisii & $\begin{array}{l}\text { - Habitus: terna (herba), tanaman menahun, terdapat } \\
\text { rimpang (rhizoma). } \\
\text { - Akar: serabut, kecil, bulat, warna putih } \\
\text { - Rimpang: tumbuh mendatar, bulat, beruas, berserat, } \\
\text { berwarna coklat muda, menghasilkan anakan dari stolon. } \\
\text { - Daun: daun tunggal, daun duduk (sessilis), tidak berupih, } \\
\text { tidak bertangkai, bangun dabus atau paku (subulatus), } \\
\text { pangkal membulat (rotundatus), ujung meruncing } \\
\text { (acuminatus) menyerupai duri (spina), permukaan licin } \\
\text { (laevis), warna hijau cerah sampai hijau tua, terdapat } \\
\text { saluran (channel) di bagian pangkal dan alur vertikal } \\
\text { sepanjang daun. } \\
\text { - Corak/motif: cross banding (garis warna) hijau muda } \\
\text { sampai hijau perak/hijau silver. } \\
\text { - Bunga: tidak ditemukan. }\end{array}$ \\
\hline 24 & Sansevieria bagamoyensis & $\begin{array}{l}\text { - Habitus: terna (herba), tanaman menahun, terdapat } \\
\text { rimpang (rhizoma). } \\
\text { - Akar: serabut, kecil, bulat, warna putih. } \\
\text { - Rimpang: tumbuh menjalar/mendatar, bulat, beruas, } \\
\text { berserat, berwarna coklat, memiliki batang yang tumbuh } \\
\text { tegak. } \\
\text { - Daun: daun tunggal, daun duduk (sessilis), tidak berupih, } \\
\text { tidak bertangkai, bangun lanset (lanceolatus), pangkal } \\
\text { membulat (rotundatus), ujung meruncing (acuminatus), } \\
\text { tepi rata (integer), permukaan atas dan bawah licin- } \\
\text { mengkilat (laevis-nitidus), memiliki duri (spina) pada } \\
\text { ujung daun, warna hijau cerah. } \\
\text { - Corak/motif: tidak ada. } \\
\text { - Bunga: tidak ditemukan }\end{array}$ \\
\hline 25 & Sansevieria ehrenbergii & $\begin{array}{l}\text { - Habitus: terna (herba), tanaman menahun, terdapat } \\
\text { rimpang (rhizoma). } \\
\text { - Akar: serabut, kecil, bulat, warna putih hingga coklat } \\
\text { - Rimpang: tumbuh menjalar/mendatar, bulat, beruas, } \\
\text { berserat, berwarna coklat. } \\
\text { - Daun: daun tunggal, daun duduk (sessilis), roset akar, } \\
\text { tidak berupih, tidak bertangkai, bangun memanjang } \\
\text { hingga lanset (oblongus-lanceolatus), pangkal membulat } \\
\text { (rotundatus), ujung runcing (acutus), tepi rata (integer) } \\
\text { berwarna putih, permukaan atas dan bawah licin (laevis), } \\
\text { warna hijau tua. } \\
\text { - Corak/motif: tidak ada. } \\
\text { - Bunga: tidak ditemukan. }\end{array}$ \\
\hline
\end{tabular}

\section{Tabel 2. Data Kuantitatif Sansevieria}

\begin{tabular}{|l|l|c|c|c|}
\hline \multirow{2}{*}{ No } & \multicolumn{1}{|c|}{ Spesies } & \multicolumn{3}{|c|}{ Parameter Kuantitatif } \\
\cline { 3 - 5 } & & $\begin{array}{c}\text { Panjang } \\
\text { (mm) }\end{array}$ & $\begin{array}{c}\text { Lebar } \\
\text { (mm) }\end{array}$ & $\begin{array}{c}\text { Tebal } \\
\text { (mm) }\end{array}$ \\
\hline 1. & Sansevieria trifasciata 'pagoda' & 120.04 & 54.04 & 2.64 \\
\hline 2. & Sansevieria trifasciata 'Gold flame' & 223.00 & 50.05 & 3.90 \\
\hline 3. & Sansevieria trifasciata 'metalica' & 277.00 & 23.01 & 2.80 \\
\hline 4. & Sansevieria trifasciata 'golden hahnii philippines' & 123.04 & 34.54 & 2.41 \\
\hline 5. & Sansevieria trifasciata 'golden hahnii Philippines mutation' & 112.01 & 33.54 & 2.55 \\
\hline 6. & Sansevieria nelsonii & 384.00 & 28.04 & 3.85 \\
\hline 7. & Sansevieria javanica & 351.00 & 12.01 & 2.04 \\
\hline
\end{tabular}




\begin{tabular}{|c|l|c|c|c|}
\hline 8. & Sansevieria trifasciata 'green' & 501.00 & 40.03 & 5.78 \\
\hline 9. & Sansevieria malawi 'midnight' & 183.00 & 41.02 & 3.02 \\
\hline 10. Sansevieria trifasciata 'gold banner twister' & 312.00 & 45.05 & 3.52 \\
\hline 11. Sansevieria trifasciata laurentii' & 625.00 & 51.01 & 3.25 \\
\hline 12. Sansevieria masoniana & 470.00 & 163.00 & 3.80 \\
\hline 13. Sansevieria patens & 430.00 & 18.01 & 20.44 \\
\hline 14. Sansevieria trifasciata 'moonshine 1' & 538.00 & 59.01 & 5.60 \\
\hline 15. Sansevieria trifasciata 'moonshine 2' & 193.00 & 80.02 & 2.86 \\
\hline 16. Sansevieria cylindrica & 623.00 & 13.53 & 16.28 \\
\hline 17. Sansevieria trifasciata 'parva stick' & 720.00 & 15.01 & 8.26 \\
\hline 18. Sansevieria aethiopica & 195.00 & 15.04 & 14.85 \\
\hline 19. Sansevieria aethiopica 'mutation' & 410.00 & 12.04 & 10.32 \\
\hline 20. Sansevieria grandis & 280.00 & 89.05 & 4.27 \\
\hline 21. Sansevieria trifasciata 'tiger stripe' & 530.00 & 50.02 & 4.25 \\
\hline 22. Sansevieria canaliculata & 625.00 & 20.03 & 18.86 \\
\hline 23. Sansevieria concinna & 70.00 & 24.00 & 2.60 \\
\hline 24. Sansevieria francisii & 490.00 & 33.04 & 3.60 \\
\hline 25. Sansevieria bagamoyensis & 199.00 & 12.04 & 3.52 \\
\hline 26. Sansevieria ehrenbergii & 158.00 & 20.04 & 5.97 \\
\hline
\end{tabular}

\section{Pembahasan}

Dari hasil penelitian yang telah dilakukan di kota Makassar, ditemukan 25 spesies sansevieria dengan morfologi yang beragam. Beberapa tanaman sansevieria hanya ditemukan di depot tanaman hias dengan nilai ekonomis tinggi, dan yang lainnya dapat ditemukan di rumah peminat tanaman hias sansevieria ataupun di rumah penduduk yang memanfaatkan sansevieria sebagai tanaman pagar.

Tanaman sansevieria di kota Makassar didominasi oleh spesies dengan warna hijau gelap hingga hijau kelabu, hanya sedikit yang berwarna hijau pucat atau memiliki kombinasi warna kuning. Begitupun dengan corak dan bentuk daun. Beberapa spesies memiliki cross banding (garis warna horizontal), yang lainnya ada yang memiliki strip atau garis vertikal, bahkan ada yang berdaun hijau polos tanpa cross banding ataupun strip vertikal seperti pada Sansevieria ehrenbergii. Berdasarkan bentuk daun, sansevieria memiliki bentuk daun yang beragam, mulai dari jorong (ovalis/ellipticus), memanjang (oblongus), lanset (lanceolatus), hingga bangun paku atau dabus (subulatus). Pada beberapa jenis sansevieria ada yang memiliki alur atau garis seperti pada Sansevieria javanica, Sansevieria patens, Sansevieria cylindrica, Sansevieria canaliculata, Sansevieria francisii serta adapula yang memiliki saluran (channel) yang terletak di bagian pangkal daun seperti pada Sansevieria patens dan Sansevieria francisii.

Berdasarkan ukuran panjang daun, ditemukan bahwa Sansevieria trifasciata 'parva stick' memiliki daun paling panjang yaitu $720 \mathrm{~mm}$ dan Sansevieria concinna memiliki daun paling pendek yaitu $70 \mathrm{~mm}$. Berdasarkan lebar daun, Sansevieria masoniana merupakan daun terlebar yaitu 163 $\mathrm{mm}$, sementara Sansevieria concinna memiliki daun paling sempit yaitu hanya $70 \mathrm{~mm}$. Selain itu, ditemukan bahwa Sansevieria patens memiliki daun paling tebal diantara spesies lainnya yaitu $20.44 \mathrm{~mm}$, dan Sansevieria javanica memiliki daun paling tipis yaitu $2.04 \mathrm{~mm}$.

Berdasarkan hasil pengamatan, ditemukan sebanyak 20 spesies yang memiliki ujung daun meruncing (acuminatus) sedangkan ujung daun yang runcing hanya sebanyak 5 spesies, dan adapula sansevieria yang memiliki duri pada ujungnya yaitu Sansevieria bagamoyensis. Selain itu pengamatan juga dilakukan terhadap permukaan dan pangkal daun. Permukaan daun sansevieria didominasi oleh permukaan yang licin-mengkilat (laevis-nitidus) dan yang lainnya memiliki permukaan licin (laevis), serta kasap (scaber), sementara pada bagian pangkalnya membulat (rotundatus).

Batang pada sansevieria mengalami modifikasi menjadi rimpang. Menurut Gembong (2007), rimpang adalah penjelmaan batang beserta daunnya yang terdapat di dalam tanah, bercabang-cabang dan tumbuh mendatar, dari ujungnya dapat tumbuh tunas yang muncul di atas 
tanah dan dapat merupakan suatu tumbuhan baru. Rimpang (rhizome) sansevieria berbentuk bulat, beruas, berwarna putih hingga kecoklatan, kadang-kadang muncul di atas tanah. Namun, adapula sansevieria yang batangnya tumbuh tegak di atas tanah seperti Sansevieria bagamoyensis. Batang biasanya akan terlihat pada waktu berbunga. Dari tengah-tengah daun akan muncul batang yang tumbuh dengan cepat, bercabang-cabang, dan mendukung bunga-bunganya.

Sansevieria memiliki akar serabut berwarna putih yang tumbuh ke segala arah. Akar pada sansevieria rata-rata berukuran kecil dan halus, namun adapula yang berukuran sedikit besar dan tebal seperti pada Sansevieria masoniana, Sansevieria patens dan Sansevieria cylindrica.

Bunga sansevieria terdapat dalam malai yang tumbuh tegak dari batang. Bunga sansevieria tergolong bunga berumah dua, dimana putik dan serbuk sari tidak berada dalam satu kuntum bunga. Bunga yang memiliki putik dinamakan bunga betina, sementara bunga yang memiliki serbuk sari disebut bunga jantan. Bunga sansaveria mengeluarkan aroma yang wangi, terutama pada malam hari (Pramono, 2008).

Terkadang, beberapa jenis sansevieria memiliki penampilan yang berbeda dari induknya. Untuk memastikan jenisnya, dapat dilakukan dengan melihat bunganya secara keseluruhan. Setiap jenis sansevieria memiliki bunga yang berbeda. Ada yang menghasilkan ratusan bunga, ada pula yang hanya memliki puluhan atau bahkan belasan kuntum, bergantung pada panjang atau pendeknya tangkai bunga. Warna bunga umumnya putih, namun adapula yang berwarna merah muda. Bunga-bunga hanya mekar selama 1 hari. Ada yang menebarkan aroma harum seperti Sansevieria parva, adapula yang tidak menghasilkan aroma seperti pada Sansevieria trifasciata. Meskipun bunganya banyak, namun karena waktu mekar yang singkat sehingga sebagian bunga gagal melakukan penyerbukan. Akibatnya, hanya sedikit bunga yang terbentuk. Buah sansevieria berbentuk seperti buah kopi, setelah matang akan berubah warna menjadi hitam (Trubus, 2008).

Salah satu contoh tanaman sansevieria yang mengalami perubahan bentuk dari induknya adalah Sansevieria aethiopica 'mutasi'. Pada tanaman tersebut, terlihat bahwa induknya memiliki bentuk/bangun daun paku (subulatus) dengan saluran (channel) dari pangkal hingga ujung, dan daun melengkung ke bawah. Penampilan berbeda terlihat pada anakannya, anakan tersebut tumbuh lebih tinggi dan tegak, warna daun menjadi lebih gelap, saluran (channel) hampir tidak ada, serta tepi daun yang kemerahan hanya terlihat di bagian ujung daun.

Keragaman morfologi sansevieria dapat dipengaruhi oleh gen yang tidak stabil, sehingga sangat mudah mengalami mutasi. Perubahan yang terjadi menyangkut warna daun, corak warna daun, atau bentuk daun. Anakan tanamn yang mengalami mutasi, sama halnya dengan hibrida, dapat menjadi kultivar atau spesies yang baru. Mutasi pada sansevieria dapat bersifat sementara, atau dapat juga bersifat permanen. Perubahan atau mutasi pada sansevieria sering disebut dengan 'chimera' (Pramono, 2008).

\section{Kesimpulan}

Tanaman sansevieria di kota Makassar didominasi oleh spesies dengan warna hijau gelap hingga hijau kelabu, hanya sedikit yang berwarna hijau pucat atau memiliki kombinasi warna kuning, memiliki bentuk atau bangun daun yang beragam, diantaranya adalah bangun jorong (ovalis/ellipticus), memanjang (oblongus), lanset (lanceolatus), hingga bangun paku atau dabus (subulatus). Mutasi merupakan salah satu faktor penyebab keragaman morfologi tanaman sansevieria di kota Makassar.

\section{Referensi}

Batubara, S.W. (2010). Pengaruh Pemberian BAP dan NAA Terhadap Morfogenesis dari Kalus Sansevieria (Sansevieria cylindrica). [Skripsi] Universitas Sumatera Utara. Medan.

Hartati, S., \& Linayanti, D. (2015). Karakterisasi Anggrek Alam Secara Morfologi dalam Rangka Pelestarian Plasma Nutfah. Universitas Sebelas Maret. Surakarta. Jurnal Agronomi Indonesia. 43 (2), 133-139. 
Imani, D. (2015). Tali Serat Berbahan Dasar Serat Alami Tanaman Lidah Mertua (Sansevieria trifasciata laurentii). [Skripsi] Universitas Sumatera Utara. Medan.

Pramono, S. (2008). Pesona Sansevieria. Agromedia Pustaka. Jakarta.

Trubus, R. (2008). Sansevieria, 200 Jenis Spektakuler. Niaga Swadaya. Jakarta.

\begin{tabular}{|l|l|}
\hline Istiqamah & $\begin{array}{l}\text { Fakultas Matematika dan Ilmu Pengetahuan Alam, Universitas Negeri } \\
\text { Makasssar, Makassar } \\
\text { E-mail: } \underline{\text { sb.istiqamah24@gmail.com }}\end{array}$ \\
\hline St. Fatmah Hiola & $\begin{array}{l}\text { Dr., S. P., M. Si., Lecture, Fakultas Matematika dan Ilmu Pengetahuan Alam, } \\
\text { Universitas Negeri Makasssar, Makassar } \\
\text { E-mail: auhiola@gmail.com }\end{array}$ \\
\hline Hilda Karim & $\begin{array}{l}\text { Dr., Ir., M. P., Lecture, Fakultas Matematika dan Ilmu Pengetahuan Alam, } \\
\text { Universitas Negeri Makasssar, Makassar } \\
\text { E-mail: } \underline{\text { hildakarim@yahoo.com }}\end{array}$ \\
\hline
\end{tabular}

